\title{
Hibiscus Sabdariffa Reduces Renal Damage in Experimental Streptozotocin-induced Diabetes
}

\author{
David O. Adeyemi, ${ }^{1}$ Olarinde S. Adewole ${ }^{1}$ \\ ${ }^{1}$ Department of Anatomy and Cell Biology, Faculty of Basic Medical Sciences, College of Health Science, Obafemi Awolowo University, Ile-Ife, \\ Nigeria
}

Disclose and conflicts of interest: none to be declared by all authors

\begin{abstract}
This study evaluated the nephroprotective and antioxidant potential of methanolic extract of Hibiscus sabdariffa L. calyx (HSCE) on normal and streptozotocin-induced diabetic Wistar rats. Type 1 diabetes mellitus was induced in Wistar rats by a single intraperitoneal injection of $80 \mathrm{mg} / \mathrm{kg}$ b.w. Streptozotocin (STZ) dissolved in $0.1 \mathrm{M}$ citrate buffer (pH 6.3). The rats were divided into five groups $(n=12)$ including normal control group, test group I, diabetic negative control, test group II, and diabetic positive control. The test groups received $1.75 \mathrm{~g} / \mathrm{kg}$ bw of HSCE by gavage for 15 days. Animals were sacrificed; their kidney tissues and serum were evaluated for histopathological and biochemical parameters. The protective effects of the extract on STZ-diabetes induced renal damage was evident from the results of the histopathological analysis and the biochemical parameters evaluated in the serum and kidney homogenates. Reduced levels of glutathione, catalase and superoxide dismutase in the kidney of diabetic rats were significantly improved in the H. sabdariffa -treated rats $(p<0.05)$. Elevated concentrations of urea and creatinin in the serum of diabetic rats were also significantly lowered $(p<0.05)$ in HSCEtreated rats. Examination of stained kidney sections revealed hydropic glomerular and tubular degenerations, Bowman space diminution, glomerular and tubular basement membrane thickening as well as excessive deposition of glycogen and collagen in the renal interstitium. The kidneys of HSCE-treated rats were protected from these pathological changes. The protective effects of the extract on STZ-diabetes-induced renal damage could be partly related to its antioxidant activity.

Keywords: Streptozotocin diabetic nephropathy; hibiscus sabdariffa; Antioxidant; Anthocyanin protocatechuic acid.
\end{abstract}

\section{Introduction}

Diabetes mellitus (DM) is a group of metabolic diseases characterized with inappropriate hyperglycemia due to either a deficiency of insulin secretion or a combination of insulin resistance and inadequate insulin secretion. ${ }^{1}$ Diabetic nephropathy, one of the most serious complications of diabetes has become the leading cause of end-stage renal failure in many countries. ${ }^{2,3}$ At present, diabetic kidney disease affects $\sim 15$ to $25 \%$ of type 1 diabetic patients ${ }^{4}$ and 30 to $40 \%$ of patients with type 2 diabetes. ${ }^{5,6}$

Diabetic nephropathy is characterized by specific renal morphological and functional alterations. Features of early diabetic renal changes are glomerular hyperfiltration, glomerular and renal hypertrophy, increased urinary albumin excretion (UAE), glomerular basement membrane (GBM) thickening, and mesangial expansion with the accumulation of extracellular matrix (ECM) proteins such as collagen, fibronectin, and laminin. Advanced diabetic nephropathy is characterized by proteinuria, a decline in renal function, decreasing creatinine clearance $(\mathrm{CrCl})$, glomerulosclerosis, and interstitial fibrosis. ${ }^{4,7}$

There are several new approaches to the treatment of diabetic nephropathy based on an ever-growing mechanistic understanding of the causes of diabetic nephropathy by the specific pathogenic roles. These agents include pharmacologic inhibitors of advanced glycation end products (AGEs) formation, protein kinase $\mathrm{C}(\mathrm{PKC})$, oxidative stress, and transforming growth factor $\beta$ (TGF- $\beta){ }^{8}$

Oxidative stress is known to play a significant role in the pathogenesis of diabetic complications. ${ }^{9}$ High levels of oxidative stress with excessive generation of free radicals, and depleted levels of free radical scavenging enzymes have been demonstrated in several studies, both in experimental animal models of diabetes and in human diabetic subjects. ${ }^{10,11}$ In type 1 diabetes, reactive oxygen species (ROS) are involved in $\beta$-cell dysfunction initiated by autoimmune reactions and inflammatory cytokines. ${ }^{12}$ In type 2 diabetes, ROS activate $\beta$ cell apoptotic pathways, impair insulin synthesis and also contribute to insulin resistance. ${ }^{13}$

There are many evidences suggesting that ROS play an important role in the pathogenesis of diabetic nephropathy. ${ }^{14}$ To prevent the development and progression of diabetic nephropathy, it would be effective in combing the strategies to prevent overproduction of ROS and to increase the removal of preformed ROS. ${ }^{14}$ 
A wide variety of natural products have been found to possess ability to control metabolic problems and oxidative stress in diabetes. Among them, Hibiscus sabdariffa L. (Malvaceae) is a valuable source of traditional medicine. ${ }^{15}$ Hibiscus sabdariffa plant is known in many countries and is consumed as hot and cold beverages popularly called "zobo" in Nigeria. It is known as roselle in English, karkade in Arabic and yakuwa, amukan/isapa and okworo ozo in Hausa, Yoruba and Ibo languages of Nigeria respectively.

Water-soluble extracts from Hibiscus sabdariffa calyx contain several antioxidants, such as polyphenolic acids, flavonoids, protocatechuic acid ${ }^{16}$ and anthocyanins. ${ }^{17}$ Recent studies have shown the potentials of these antioxidants in the protection of kidney in chemically-induced kidney damage. ${ }^{18,19}$ Hence, this study investigates the potential nephroprotective properties of the polyphenol-rich extract of Hibiscus sabdariffa in animal model of STZdiabetes-induced kidney damage.

\section{Materials and Methods}

\section{Chemicals}

All chemicals used were of analytical grade. STZ was purchased from Sigma-Aldrich (St. Louis, MO, USA). Biochemical kits for creatinine and urea assay were purchased from Randox Laboratory (Crumlin, Co. Antrim, UK). Biochemical kits for catalase, GSH, GPx and TBARS assay were purchased from Bio Assay System (Hayward, CA 94545, USA) while the kit for SOD assay was purchased from Cell Technology Inc. (Mountain View, CA 94043). Other histological reagents and stains were purchased from Sigma-Aldrich (St. Louis, MO, USA)

\section{Animals}

Healthy Wistar rats $(150-200$ g) of both sexes obtained from the animal holding of the College of Health Sciences, Obafemi Awolowo University Ile-Ife were used for the experiment. They were maintained under standard environmental conditions of temperature, humidity and light and fed on standard rat pellets (Ladokun Feeds, Ibadan, Nigeria) and water ad libitum. The animals were acclimatized to the laboratory for four weeks. The rats received humane care according to the criteria stipulated in the Guide for the Care and Use of Laboratory Animals, prepared by the Institute of Laboratory Animal Research, National Research Council, USA ${ }^{20}$ and their experimental use was approved by the Health Research and Ethics Committee of Obafemi Awolowo University Ile Ife.

\section{Experimental Design}

The animals were randomly assigned into five groups A, B, C, D and E of twelve rats each. Group A was normal control (normoglycemic rats); group B was test group I (normoglycemic rats treated with Hibiscus sabdariffa calyx extract); group $\mathrm{C}$ was diabetic negative control (untreated diabetic rats given STZ as described in "Induction of Experimental Diabetes" section); group D was test group II (diabetic rats treated with HSCE); while group E was diabetic positive control (diabetic rats treated with protamin zinc insulin). The design of the experiment followed a previously reported scheme shown in Fig. $1 .^{21}$

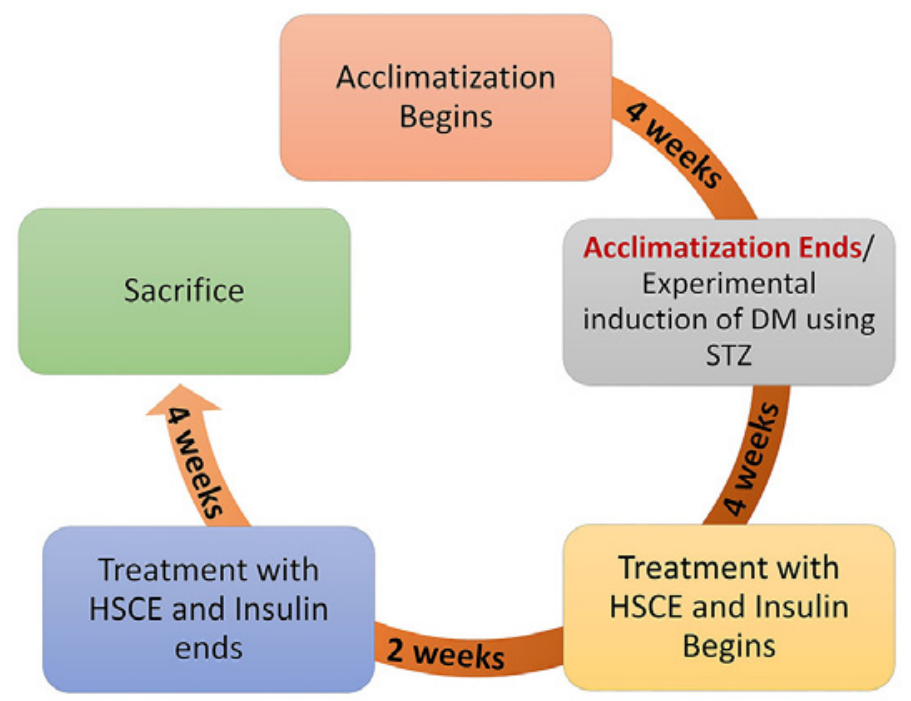

Figure 1. Schematic diagram of the experimental design.

\section{Plant Material and Extraction}

Hibiscus sabdariffa calyx extract was prepared as previously reported ${ }^{21,22}$. Dried and pulverized calyxes of H. sabdariffa $(200 \mathrm{~g})$ were extracted three times with $70 \%$ methanol $(500 \mathrm{~mL} \times 3)$ and continuously stirred at room temperature for 24 hours each. The extract was concentrated in vacuo at $25^{\circ} \mathrm{C}$ using a vacuum rotary evaporator (RE 100B, Bibby Sterilin, United Kingdom) and the aqueous phase was partitioned with ethyl acetate (EtOAc). The aqueous fraction (coded HSCE) was freeze dried using a vacuum freeze drier (FT33Armfield, England) and used for the experiment.

\section{Phytochemical Analysis}

Phytochemical analysis of alkaloids, anthocyanins, flavonoids, phenols, saponins, tannins coumarins, triterpens and steroids was performed on calyx of Hibiscus sabdariffa as earlier reported. ${ }^{22-24}$

\section{Induction of Experimental Diabetes and Drug Administration}

Animals were fasted (but still allowed access to water) for 16 hours prior to induction. Diabetes mellitus was induced in groups $\mathrm{C}, \mathrm{D}$ and $\mathrm{E}$ rats by a single i.p. injection of $80 \mathrm{mg} / \mathrm{kg}$ bw STZ dissolved in 0.1 M sodium citrate buffer (pH 6.3) as previously reported..$^{22,25,26}$ Group A rats were injected with equivalent volumes of citrate buffer i.p. Four weeks post induction of diabetes, daily 
doses of $1.75 \mathrm{~g} / \mathrm{kg}$ bw HSCE was administered orally to the rats in test groups I and II (groups B and D) for 15 days by gavage, while group $\mathrm{E}$ rats (diabetic positive control) were treated with $1 \mathrm{IU} / \mathrm{kg} /$ day of protamine zinc insulin. Rats in group C (diabetic negative control) were left untreated.

\section{Sacrifice}

A mid-line incision was made through the anterior abdominal walls of the rats under terminal chloroform anesthesia. The kidney tissues were excised and weighed. Some of the tissues were fixed in $10 \%$ formol saline for 48 hours for histological procedures. Some others were fixed in Bouin's oxative for 24 hours for histochemical procedure, while other parts were frozen for biochemical assay.

\section{Determination of Kidney Weight}

At sacrifice, the absolute weight of the kidneys was measured using a top loader sensitive balance. The relative weight of the kidney (\%) was calculated from the body weight at sacrifice and the average of the absolute weights of the two kidneys as earlier described. ${ }^{26}$

Relative weight of the kidney $=\frac{\text { Average Absolute kidney weight }}{\text { Body weight at sacrifice }} \times 100$

\section{Histological and Histochemical Procedures}

Kidney tissues fixed in $10 \%$ formol saline were processed via paraffin wax embedding method. ${ }^{27}$ Sections of $4 \mathrm{~mm}$ thickness produced were stained with haematoxylin and eosin (HE) for general histological examination of the kidney tissues and with Masson trichrome stain (MT) to histologically demonstrate collagen fibers in kidney. The tissues fixed in Bouin's dxative were processed via paraffin wax embedding. Sections of $4 \mathrm{~mm}$ thickness produced were stained with PAS with diastase control to histochemically demonstrate glomerular and tubular basement membranes in the kidney sections. The sections were examined under Leica DM750 research microscope with a digital camera (Leica ICC50) attached. Digital photomicrographs were taken at various magnifications.

\section{Histomorphometry}

All histomorphometric studies were performed on Leica DM750 research microscope connected to a digital camera (Leica ICC50) and a laptop computer (Acer Aspire One) with Image J 1.42q and open office. org image analysis software installed. The kidney sections were examined at different magnifications and the following parameters were measured: (a) the maximum glomerular diameter, (b) the maximum width of the Bowman space, (c) proximal convoluted tubule (PCT) trans-luminal diameter (d) distal convoluted tubule (DCT) trans-luminal diameter and (e) PCT and DCT epithelial thickness. The trans-luminal diameter of PCT and DCT were derived by measuring the maximum diameter $\left(D_{1}\right)$ and minimum diameter $\left(D_{2}\right)$ at right angle to the maximum diameter. The transluminal diameter (D) and the cross-sectional area $\left(\mathrm{A}_{\mathrm{c}}\right)$ of the renal tubules (PCT and DCT) were calculated using the following equations:

$D=\sqrt{ } D_{1} D_{2} A c=\frac{\partial D^{2}}{4}$ where $ð$ is equivalent to 3.142

\section{Biochemical Assays}

\section{Collection of Blood Samples}

Blood samples were obtained from the rats by cardiac puncture at sacrifice and were kept for 30 minutes at room temperature. Serum was separated from the blood samples by centrifugation at $5000 \mathrm{rpm}$ for 10 minute at room temperature.

\section{Assay for Kidney Function Markers}

Serum marker of kidney (creatinine and urea) were estimated spectrophotometrically, using enzymatic colorimetric assay kits (Randox, Crumlin, Co. Antrim, $\mathrm{UK})$.

\section{Preparation of Kidney Homogenates}

The excised kidney was divided into separate portions for the estimation of catalase (CT), superoxide dismutase (SOD), glutathione peroxidase (GPX), glutathione (GSH) and thiobarbituric reactive substances (TBARS). Homogenates were obtained for each of the assays as previously described. ${ }^{22}$

Biochemical Assay for Antioxidants and Lipid Peroxidation Markers

The activities of CT, SOD and GPX as well as the concentration of GSH and TBARS were determined in the resulting supernatants by a 96-well microplatebased assay using their specific quantitative colorimetric detection kits following manufacturers manual. ${ }^{28-32}$

\section{Statistical Analysis}

All values were presented as mean \pm standard error of mean (SEM) for twelve rats in each of the five group of rats. The significance of difference in the means of all parameters was determined using one-way analysis of variance (ANOVA; 95\% confidence interval). Dunnett multiple comparison (DMC) and Student NewmanKeul's (SNK) post hoc tests were performed for comparison of all groups with control and comparison of all pairs of groups respectively. All statistics were performed in GraphPad Prism. Values of $p<0.05$ were considered as significant. ${ }^{33}$

\section{Results}

Phytochemical Constituents of Hibiscus Sabdariffa

Phytochemical screening of HSCE in this study revealed the following constituents: flavonoids, phenols, tannins, saponins, alkaloids, triterpenes and steroids (Table 1). Anthocyanins (delphinidin3-sambubioside and cyanidin-3-sambubioside), flavonoids (protocatechuic acid and quercetin-3- 
rutinoside) and organic acids (hydroxycitric acid and hibiscus acid) had been previously isolated from extracts of Hibiscus sabdariffa calyx. ${ }^{34-37}$ The chemical structures of these constituents and their percentage compositions are shown in Table $2 .{ }^{38}$

Table 1. Phytochemical Screening of Hibiscus sabdariffa Calyx Extract

\begin{tabular}{l|c}
\multicolumn{1}{c|}{ Class of Compounds } & Ethanol Extract \\
\hline Alkaloids & + \\
\hline Flavonoids & +++ \\
\hline Saponins & ++ \\
\hline Anthocyanins & +++ \\
\hline Tannins & + \\
\hline Triterpene and steroids & + \\
\hline Phenols & ++ \\
\hline Coumarins & - \\
\hline
\end{tabular}

Note: (-): Absence; (+): Less presence; (++): Moderate presence; $(+++)$ Abundant presence

\section{Effects of HSCE on Kidney Weight}

The effects of HSCE on the body weight, absolute and relative kidney weight in all groups of rats are shown in Table 3. The diabetic positive and negative controls presented with severe loss in body weight and absolute kidney weight when compared with the other groups. However, the relative weight of the kidneys with respect to the body weight was not significantly different in all groups.

\section{Effects of HSCE on Kidney Function Markers}

The concentrations of creatinin, urea, total protein and albumin in normoglycemic, diabetic negative and positive controls, and extract treated groups are presented in Table 4. The concentrations of creatinin and urea significantly increased $(p<0.05)$ in the serum of diabetic negative control rats when compared with the normoglycemic rats. Administration of HSCE significantly lowered $(p<0.05)$ the serum level of these kidney function markers in test group II rats better than that demonstrated by protamin zinc

Table 2. Chemical structure of isolated compounds from Hibiscus sabdariffa calyx

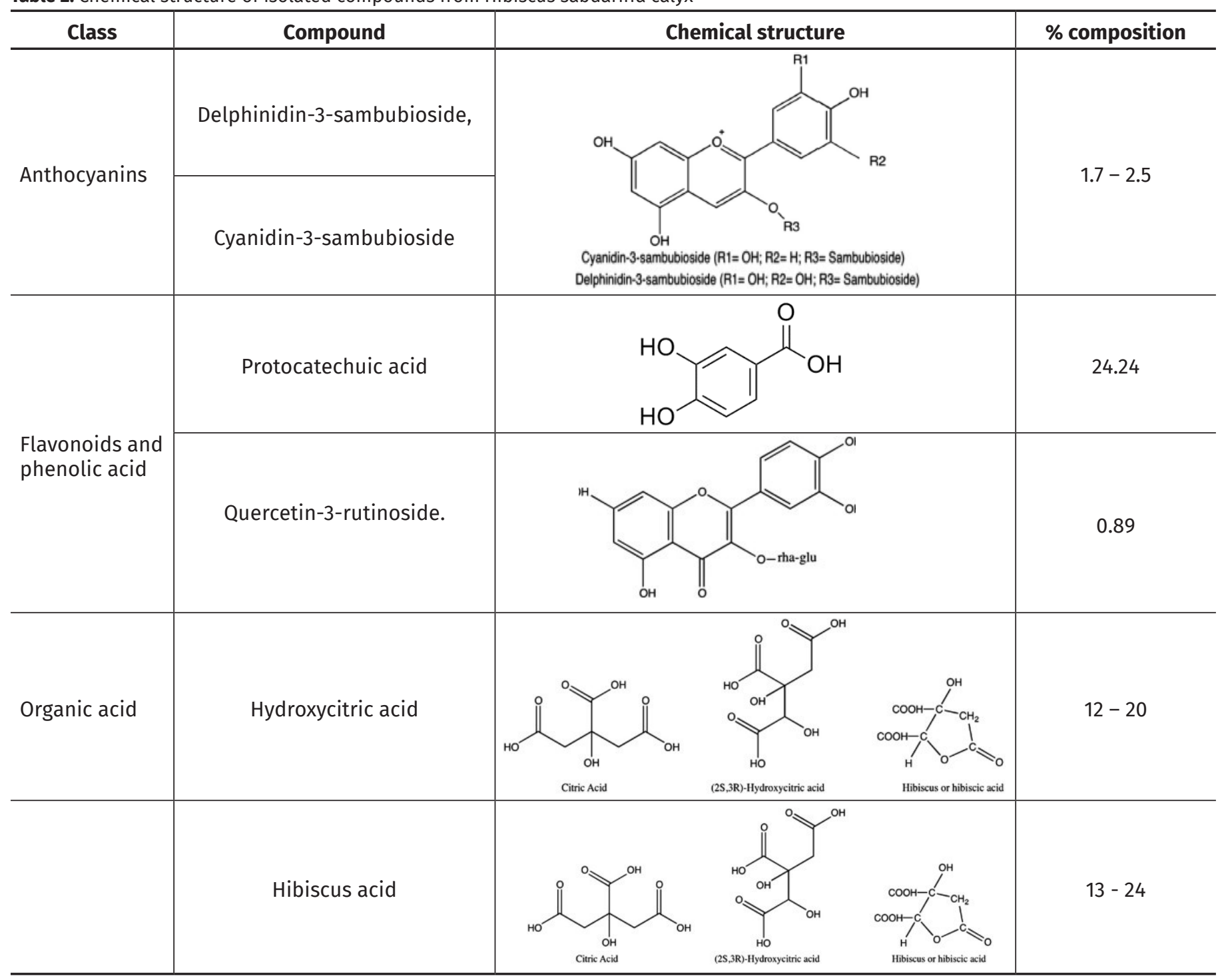


insulin administration in the positive control group. HSCE had no significant effect on the serum levels of urea and creatinin in normoglycaemic rats. On the other hand, the levels of total protein and albumin were significantly reduced $(p<0.05)$ in the serum of diabetic negative control rats when compared with the normoglycemic rats. However, the serum levels of total protein and albumin were comparable in the normogycemic and test groups I and II rats.

Table 3. Effects of H. Sabdariffa on body weight and kidney weight

\begin{tabular}{l|c|c|c}
\hline & $\begin{array}{c}\text { Body weight } \\
\text { (g) }\end{array}$ & $\begin{array}{c}\text { Absolute } \\
\text { kidney } \\
\text { weight } \\
\text { (g) }\end{array}$ & $\begin{array}{c}\text { Relative } \\
\text { kidney } \\
\text { weight } \\
\text { (\%) }\end{array}$ \\
\hline $\begin{array}{l}\text { A (normal } \\
\text { control) }\end{array}$ & $181.92 \pm 6.49 \dagger$ & $0.74 \pm 0.06 \dagger$ & $0.41 \pm 0.03 \dagger$ \\
\hline B (Test I) & $179.75 \pm 7.11 \dagger$ & $0.72 \pm 0.07 \dagger$ & $0.40 \pm 0.04 \dagger$ \\
\hline $\begin{array}{l}\text { C (Diabetic -ve } \\
\text { control) }\end{array}$ & $\begin{array}{c}141.58 \pm 3.33 \\
\star \mp\end{array}$ & $0.52 \pm 0.05^{*} \ddagger$ & $0.37 \pm 0.02 \dagger$ \\
\hline D (Test II) & $168.17 \pm 6.15 \dagger$ & $0.68 \pm 0.05 \dagger$ & $0.40 \pm 0.03 \dagger$ \\
\hline $\begin{array}{l}\text { E (Diabetic +ve } \\
\text { control) }\end{array}$ & $\begin{array}{c}139.41 \pm \\
2.55^{*} \ddagger\end{array}$ & $0.54 \pm 0.04^{*} \ddagger$ & $0.39 \pm 0.03 \dagger$
\end{tabular}

${ }^{*} p<0.05$ compared with the normal control, determined by one way ANOVA followed by DMC post hoc test.

$\dagger \neq$ within column signifies $p<0.05$ between groups with different symbols, determined by SNK post hoc test

Table 4. Effects of $H$. Sabdariffa on the kidney function markers

\begin{tabular}{l|c|c}
\hline & $\begin{array}{c}\text { Creatinin } \\
(\mu \mathrm{mol} / \mathrm{L})\end{array}$ & $\begin{array}{c}\text { Urea } \\
(\mathrm{mmol} / \mathrm{L})\end{array}$ \\
\hline $\mathrm{A}$ (normal control) & $77.20 \pm 6.15 \dagger$ & $3.89 \pm 0.94 \dagger$ \\
\hline $\mathrm{B}$ (Test I) & $65.02 \pm 5.13 \dagger$ & $3.35 \pm 0.83 \dagger$ \\
\hline $\mathrm{C}$ (Diabetic -ve control) & $305.46 \pm 11.84^{*} \ddagger$ & $11.87 \pm 1.85^{\star} \ddagger$ \\
\hline $\mathrm{D}$ (Test II) & $103.32 \pm 6.17 \dagger$ & $7.83 \pm 1.34^{\star} \S$ \\
\hline $\mathrm{E}$ (Diabetic +ve control) & $283.62 \pm 9.79^{*} \ddagger$ & $9.03 \pm 1.45^{\star} \S$ \\
\hline
\end{tabular}

* $p<0.05$ compared with the normal control, determined by one way ANOVA followed by DMC post hoc test.

$\dagger \ddagger \S$ within column signifies $p<0.05$ between groups with different symbols, determined by SNK post hoc test

\section{Effects of HSCE on Kidney Antioxidants}

The activities of the antioxidant enzymes (catalase, superoxide dismutase and glutathione peroxidase) and the concentration of glutathione (a non-enzymatic antioxidant) were significantly reduced $(p<0.05)$ in the kidney homogenates of the diabetic negative control rats compared with normoglycemic rats (Table 3). HSCE treatment elevated the activities of these antioxidant enzymes and concentration of glutathione significantly $(p<0.05)$ in the kidney of test group II rats better than that demonstrated by protamin zinc insulin in the diabetic positive control group (Table 5). However, HSCE treatment had no significant effect on these antioxidants in the kidney of normoglycemic rats.

\section{Effects of HSCE on Lipid Peroxidation}

The concentration of TBARS, a marker of lipid peroxidation was significantly higher $(p<0.05)$ in the kidney of diabetic negative control rats than in normoglycemic rats (Table 5). However, HSCE treatment lowered the level of TBARS significantly $(p<$ $0.05)$ in the treated diabetic rats.

Table 5. Effects of $H$. Sabdariffa on the antioxidants and lipid peroxidation marker in kidney homogenate

\begin{tabular}{|c|c|c|c|c|c|}
\hline & $\begin{array}{c}C T \\
(U / L)\end{array}$ & $\begin{array}{l}\text { GPX } \\
(U / L)\end{array}$ & $\begin{array}{l}\text { SOD } \\
(\mathrm{U} / \mathrm{mL})\end{array}$ & $\begin{array}{l}\text { GLU } \\
(\mu \mathrm{M})\end{array}$ & $\begin{array}{c}\text { TBARS } \\
(\mu \mathrm{M} \text { MDA) }\end{array}$ \\
\hline $\begin{array}{l}\text { A (normal } \\
\text { control) }\end{array}$ & $\begin{array}{c}0.86 \pm \\
0.07 \dagger\end{array}$ & $\begin{array}{l}1.12 \pm \\
0.07 \dagger\end{array}$ & $\begin{array}{c}98.76 \pm \\
5.02 \dagger\end{array}$ & $\begin{array}{l}7.34 \pm \\
0.65 t\end{array}$ & $\begin{array}{c}8.05 \pm \\
0.73+\end{array}$ \\
\hline B (Test I) & $\begin{array}{l}0.91 \pm \\
0.05 t\end{array}$ & $\begin{array}{l}1.17 \pm \\
0.07 \dagger\end{array}$ & $\begin{array}{c}94.55 \pm \\
3.11 \dagger\end{array}$ & $\begin{array}{l}7.56 \pm \\
0.71 \dagger\end{array}$ & $\begin{array}{l}9.01 \pm \\
0.55 t\end{array}$ \\
\hline $\begin{array}{l}\text { C (Diabetic } \\
\text {-ve control) }\end{array}$ & $\begin{array}{l}0.47 \pm \\
0.03^{*} \ddagger\end{array}$ & $\begin{array}{l}0.68 \pm \\
0.05^{*} \pm\end{array}$ & $\begin{array}{c}45.38 \pm \\
2.91^{*} \neq\end{array}$ & $\begin{array}{l}2.08 \pm \\
0.33^{*} \pm\end{array}$ & $\begin{array}{l}16.49 \pm \\
0.96^{\star} \ddagger\end{array}$ \\
\hline D (Test II) & $\begin{array}{l}0.79 \pm \\
0.04 \dagger\end{array}$ & $\begin{array}{l}0.78 \pm \\
0.06^{*} \ddagger\end{array}$ & $\begin{array}{c}92.17 \pm \\
4.02 \dagger\end{array}$ & $\begin{array}{l}7.03 \pm \\
0.57 \dagger\end{array}$ & $\begin{array}{l}9.24 \pm \\
0.58 t\end{array}$ \\
\hline $\begin{array}{l}\text { E (Diabetic } \\
\text { +ve } \\
\text { control) }\end{array}$ & $\begin{array}{c}0.55 \pm \\
0.03^{*} \neq\end{array}$ & $\begin{array}{c}0.72 \pm \\
0.04^{*} \ddagger\end{array}$ & $\begin{array}{l}36.79 \pm \\
2.68^{\star} \S\end{array}$ & $\begin{array}{l}2.65 \pm \\
0.31^{*} \neq\end{array}$ & $\begin{array}{l}11.73 \pm \\
0.86^{\star} \S\end{array}$ \\
\hline
\end{tabular}

* $p<0.05$ compared with the normal control, determined by one-way ANOVA followed by DMC post hoc test.

$\dagger \ddagger \S$ within column signifies $p<0.05$ between groups with different symbols, determined by SNK post hoc test.

\section{Histopathological Assessment of the Kidney}

Histological study of the kidney of normoglycaemic rats showed normal glomerulus (G) surrounded by bowman capsule (arrow), proximal convoluted tubules (P) and distal convoluted tubules (D)(Fig. 2). Examination of the sections of the kidney of STZ diabetic rats revealed an array of pathological changes including hydropic glomerular and tubular degenerations $(\mathrm{H})$, Bowman space diminution (Figs. 2 and 3), accumulation of collagen fibers (Fig. 3), glomerular and tubular basement membrane thickening, as well as excessive glycogen deposition (Fig. 4). These pathological changes which persisted in diabetic positive control rats treated with protamin zinc insulin were ameliorated in the kidneys of test group II rats treated with HSCE (Figs. 2, 3 and 4). However, HSCE had no effects on the kidneys of normoglycaemic rats.

\section{Histomorphometry}

The maximum width of Bowman space in the diabetic negative control group was significantly $(p<$ $0.05)$ lower than that of the normoglycaemic group of rats (Table 6). This diminution persisted in the diabetic positive control group treated with protamin zinc insulin. However, the width of bowman space in the kidney section of the groups treated with HSCE was not significantly different from that of normoglycaemic 
rats (Table 6). The trans-luminal diameter and cross sectional area of the proximal convoluted tubules were significantly $(p<0.05)$ lower in the diabetic negative and positive control groups than those of the normoglycaemic and the test groups (Table 7). The transluminal diameter of the distal convoluted tubule was significantly higher $(p<0.05)$ in the diabetic negative control group than in the other groups.
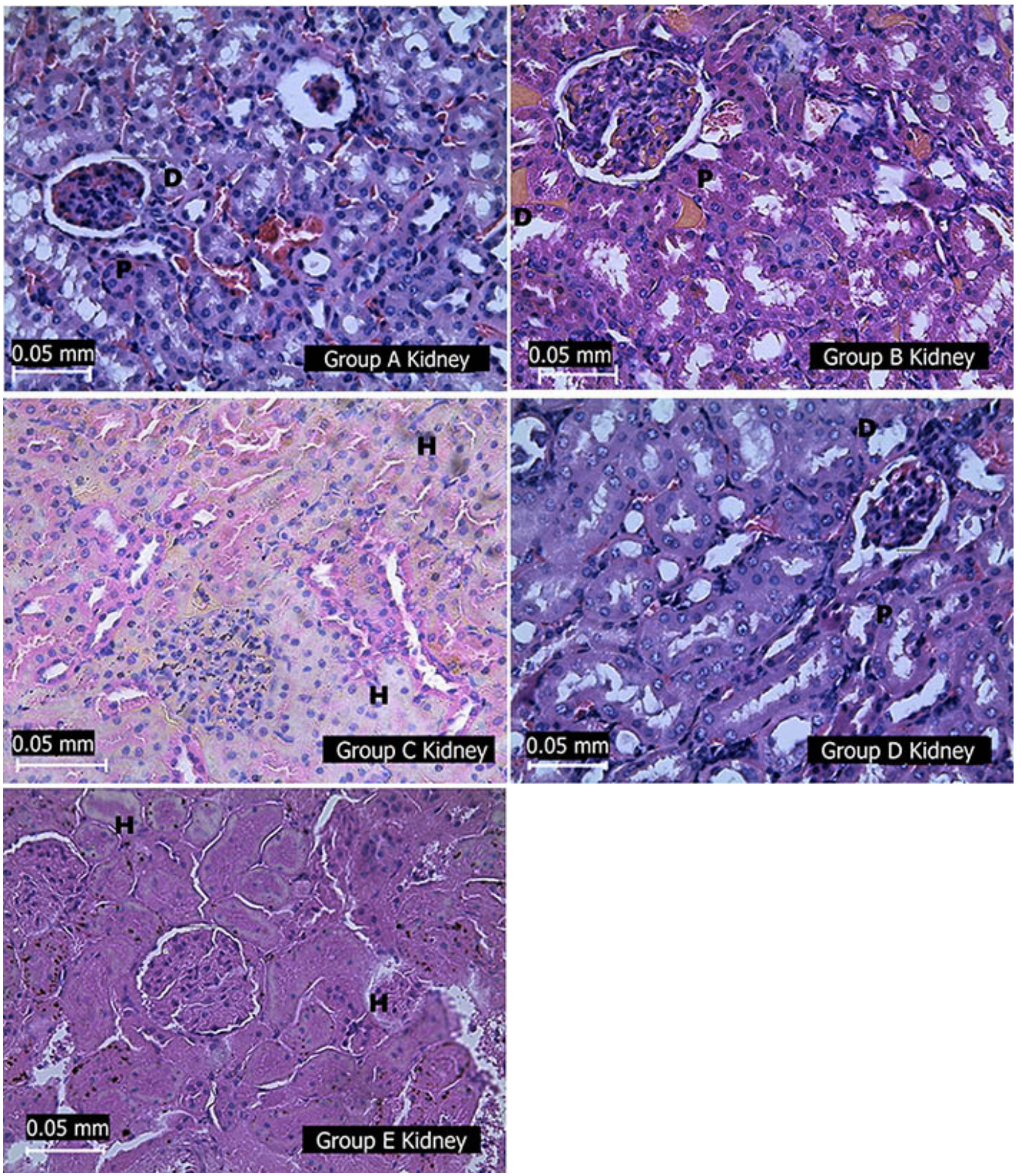

Figure 2. Photomicrographs of $\mathrm{H} \& \mathrm{E}$ stained paraffin section from the cortex of the kidneys of experimental rats (A - normoglycaemic rats, B - test group I, C - diabetic negative control, D - test group II and E - diabetic positive control). The glomerulus (G) is surrounded by the Bowman space (arrow), proximal convoluted tubules $(P)$ and distal convoluted tubules (D). Pathological changes including hydropic glomerular and tubular degenerations $(\mathrm{H})$ and Bowman space diminution were observed in the kidneys of groups $\mathrm{C}$ and $\mathrm{E}$ rats. The kidney sections of groups $A, B$ and $D$ rats appeared normal. 

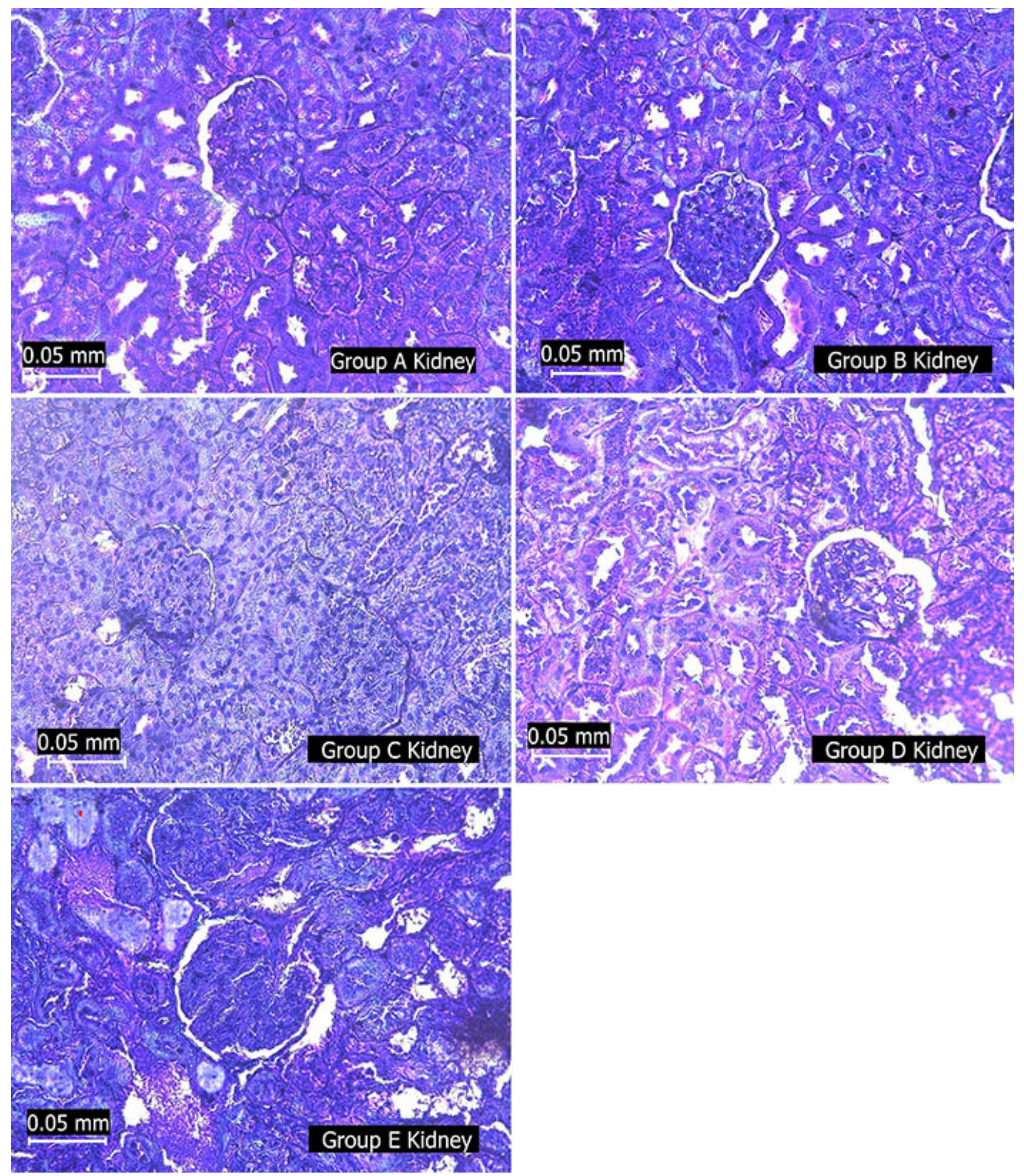

Figure 3. Photomicrographs of Massons trichrome stained paraffin section from the cortex of the kidneys of the experimental rats (A normoglycaemic rats, B - test group I, C - diabetic negative control, D - test group II and E - diabetic positive control). Extensive area of renal interstitium showed the presence of collagen (light green stained area) in the kidneys of groups C and E rats. The kidney sections of groups A, B and $D$ rats appeared normal 

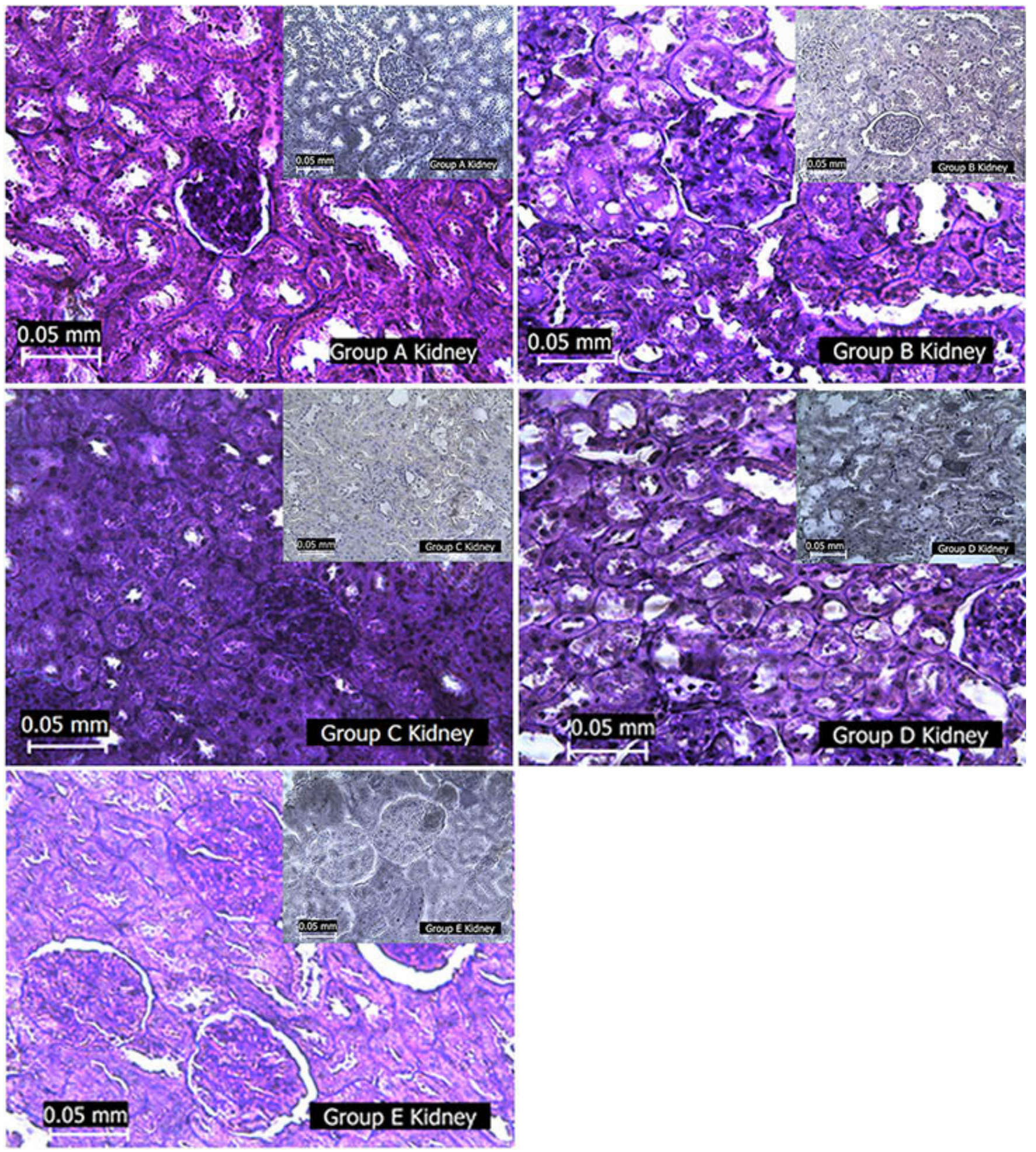

Fig. 4 Photomicrographs of section from the cortex of the kidneys of experimental rats (A - normoglycaemic rats, B - test group I, C - diabetic negative control, D - test group II and E - diabetic positive control) stained with PAS with diastase control (inset). Glomerular and tubular basement membranes (arrow) and glycogen were well demonstrated in the kidney of normoglycaemic and test group II rats. Kidney sections of the diabetic negative and positive control rats showed thickening of basement membrane as well as excessive glycogen deposits. These abnormal features are absent in the kidney of test group I rats. 
Table 6. Kidney glomerular morphometry results

\begin{tabular}{|c|c|c|c|}
\hline Groups & $\begin{array}{l}\text { Maximum } \\
\text { Glomerular } \\
\text { Diameter } \\
(\mathrm{mm})\end{array}$ & $\begin{array}{c}\text { Maximum Width } \\
\text { of the Bowman } \\
\text { Space } \\
\left(\mathrm{mm}^{2}\right)\end{array}$ & $\begin{array}{c}\text { Number of } \\
\text { Glomeruli / } \\
\text { unit area of } \\
\text { cortex } \\
\left(\mathrm{N} / 10^{5} \mathrm{~mm}^{2}\right)\end{array}$ \\
\hline $\begin{array}{l}\text { A (normal } \\
\text { control) }\end{array}$ & $92.13 \pm 7.340$ & $8.84 \pm 1.275$ & $1.16 \pm 0.163$ \\
\hline B (Test I) & $97.00 \pm 4.704$ & $12.12 \pm 1.754$ & $1.70 \pm 0.177$ \\
\hline $\begin{array}{l}\text { C (Diabetic } \\
\text {-ve control) }\end{array}$ & $\begin{array}{c}110.13 \pm \\
4.552\end{array}$ & $2.58 \pm 0.043^{*}$ & $0.80 \pm 0.179$ \\
\hline D (Test II & $95.06 \pm 2.719$ & $11.83 \pm 2.292$ & $1.16 \pm 0.213$ \\
\hline $\begin{array}{l}\text { E (Diabetic } \\
+ \text { ve control) }\end{array}$ & $\begin{array}{c}112.31 \pm \\
7.234\end{array}$ & $4.50 \pm 0.548$ * & $0.98 \pm 0.126$ \\
\hline
\end{tabular}

* $p<0.05$ compared with the normal control, determined by one way ANOVA followed by DMC post hoc test.

Table 7. Kidney Tubular Morphometry Results treatment of $H$. sabdariffa also decreased the level of MDA in the diabetic rats. The increase in antioxidants provides effective protection from oxidative damage. The anthocyanins and protocatechuic acid, a phenolic compound present in the extract of $H$. sabdariffa calyx are likely responsible for this strong antioxidant activity.

Histopathological examinations of the kidney sections revealed that STZ diabetic rats as well as insulin-treated diabetic rats manifested with variable extent of kidney damage marked by necrosis of the glomerulus and its infiltration with fats; glomerular enlargement, obliterating the Bowman space, thickening of the glomerular and tubular basement membranes; glycogen deposition in the interstitium and renal interstitial fibrosis, indicated by the presence of collagen in the trichrome-stained kidney sections. Examination of the kidney sections of $H$. sabdariffa extract-treated diabetic rats showed that this extract

\begin{tabular}{l|c|c|c|c|c|c}
\hline \multicolumn{1}{|c|}{ Groups } & $\begin{array}{c}\text { PCT trans-luminal } \\
\text { diameter } \\
(\mu \mathrm{m})\end{array}$ & $\begin{array}{c}\text { DCT trans-luminal } \\
\text { diameter } \\
(\mu \mathrm{m})\end{array}$ & $\begin{array}{c}\text { PCT cross } \\
\text { sectional area } \\
\left(\mu \mathrm{m}^{2}\right)\end{array}$ & $\begin{array}{c}\text { DCT cross } \\
\text { sectional area } \\
\left(\mu \mathrm{m}^{2}\right)\end{array}$ & $\begin{array}{c}\text { PCT epithelial } \\
\text { height }(\mu \mathrm{m})\end{array}$ & $\begin{array}{c}\text { DCT epithelial } \\
\text { height }(\mu \mathrm{m})\end{array}$ \\
\hline $\begin{array}{l}\text { A (normal } \\
\text { control) }\end{array}$ & $23.99 \pm 3.62$ & $32.45 \pm 1.54$ & $524.21 \pm 35.44$ & $836.35 \pm 76.51$ & $17.83 \pm 0.14$ & $10.42 \pm 0.11$ \\
\hline B (Test I) & $23.96 \pm 1.36$ & $27.77 \pm 3.06$ & $461.15 \pm 47.00$ & $631.66 \pm 89.21$ & $17.73 \pm 0.32$ \\
\hline $\begin{array}{l}\text { C (Diabetic } \\
\text {-ve control) }\end{array}$ & $10.88 \pm 0.63^{*}$ & $40.37 \pm 1.50^{*}$ & $95.13 \pm 10.27 *$ & $1288.76 \pm 97.80 *$ & $14.44 \pm 1.05$ & $6.59 \pm 0.29 *$ \\
\hline D (Test II) & $25.08 \pm 0.48$ & $30.16 \pm 1.85$ & $495.26 \pm 18.45$ & $728.13 \pm 91.51$ & $16.92 \pm 1.40$ \\
\hline $\begin{array}{l}\text { E (Diabetic } \\
+ \text { ve control) }\end{array}$ & $16.88 \pm 0.73 *$ & $35.20 \pm 2.29$ & $226.74 \pm 20.32 *$ & $993.88 \pm 120.56$ & $12.91 \pm 2.12 *$ & $7.06 \pm 0.19 *$ \\
\hline
\end{tabular}

* $p<0.05$ compared with the normal control, determined by one way ANOVA followed by DMC post hoc test.

\section{Discussion}

Several studies have documented that oxidative stress is accelerated in diabetes mellitus owing to an increase in the production of oxygen free radicals, lipid peroxidation and low-density lipoprotein. ${ }^{39}$ Free radicals can diffuse intracellularly and result in mitochondrial enzyme damage and DNA breakages, all of which impair cellular function and contribute to the pathophysiology of diabetes. ${ }^{10}$ Oxygen free radicals exert their cytotoxic effects on membrane phospholipids, resulting in the formation of MDA. As a product of lipid peroxidation, the levels of MDA reflect the degree of oxidation in the body. As components of the free radical scavenging system, SOD, CT and GPx exist in all oxygen-metabolizing cells, to prevent damage to cells by free radicals and provide a repair mechanism for oxidized membrane components. $^{40,41}$ In the present study, diabetic nephropathy was significantly improved in rats treated with $\mathrm{H}$. sabdariffa. Furthermore, we observed a significant increase in SOD, CT and GPx activities in $H$. sabdariffa-treated diabetic groups compared with the diabetic positive and negative control groups. The has nephroprotective activities on the diabetic nephropathy rat models. There was no indication of interstitial fibrosis, glomerular and tubular basement membrane thickening, glomerular necrosis and enlargement in the kidney sections of these extracttreated rats. The result of this study is in agreement with previous reports ${ }^{42,43}$ on the nephroprotective activity of extracts of $H$. sabdariffa on diabetic nephropathy models in rats.

The present study also revealed that renal tubules presented with hydropic change; characterized by pale and swollen change of the proximal convoluted tubules in STZ diabetic rats, as reported previously. ${ }^{44}$ This may be a manifestation of osmotic diuresis resulting from high glucose concentration. Administration of $H$. sabdariffa extract significant improved these edematous changes in renal proximal tubules.

Previous studies have shown oxidative stress increasing and anti-oxidative abilities reducing in diabetes. $^{45}$ Oxidative stress results in glomerular sclerosis, renal tubular injury, proteinuria and leads to gradual loss of renal function. ${ }^{46}$ A detailed pathogenesis of diabetic nephropathy is still not clear. It is considered as primarily a glomerular 
disease, including thickening of glomerular basement membrane, mesangial expansion and podocyte loss. However, recent evidence demonstrates that chronic hypoxia of the tubule interstitium has a pathogenic role in diabetic nephropathy. ${ }^{47}$ In this study, typical diabetic pathological change of Kimmelsteil-Wilson nodules in glomerulus was not found; this might result from too short duration to induce obvious glomerular changes. Indeed, only a minor change had been reported in early diabetic renal tubular injury. ${ }^{48}$ Antioxidants generally mitigate any form of oxidative stress or its consequences. They act either by directly scavenging free radicals or increasing antioxidative defenses. A major limitation to the use of antioxidant supplementation is their pro-oxidant activity and potential deleterious effects on ROS production especially when precise modulation of ROS levels are needed to allow normal cell function. ${ }^{49}$ The removal of too many ROS and their derived products by antioxidant supplementation may upset the cell signaling pathways and actually increase the risk of chronic disease. ${ }^{50}$ The results of this study showed that methanol extract of Hibiscus sabdariffa, despite improving antioxidant status in diabetic rats, had no significant effect on normal rats. The extract at the given dose was able to maintain optimal antioxidant status and does not exhibit pro-oxidant effects in normal rats.

The concentration of serum creatinin and urea increased significantly in diabetic rats as earlier reported.$^{51}$ However, H. sabdariffa extract significantly reduced the serum concentration of creatinin and urea in these rats. This is an indication of improvement in the clearance of these metabolites. In addition, hypoproteinaemia and hypoalbuminaemia were observed in the untreated diabetic rats as previously reported. ${ }^{52,53}$ These conditions, which are closely related to proteinuria were mitigated in the $\mathrm{H}$. sabdariffa - treated diabetic rats (Table 4).

\section{Conclusion}

The results obtained from this study suggest that anthocyanins and protocatechuic acid present in $\mathrm{H}$. sabdariffa mitigated experimentally-induced diabetic nephropathy in rat by protecting the kidney from oxidative damage. This study provides an important therapeutic basis for treatment of kidney diseases in insulin deficient diabetes

\section{Acknowledgments}

Author is grateful to the authorities of Obafemi Awolowo University Ile Ife for providing laboratory space and equipments for the research, Prof. C.A. Adebajo, department of Pharmacognosy for his useful suggestions and comment and to Mr. Emiola Gbela (retired Chief Technologist, Department of Morbid anatomy and Forensic Medicine, OAU) for his technical assistance in the production of the microscopic slides.

\section{References}

1. Masharani U. Diabetes mellitus and hypoglycemia. in: Papadakis, M.A., McPhee, S.J Rabow, M.W. (Eds.) Current medical diagnosis and treatment, fifty-seventh edition, McGraw-Hill, New York, 2018; 1032 $-1073</ e d b>$

2. Schrijvers BF, De Vriese AS, Flyvbjerg A. From hyperglycemia to diabetic kidney disease: the role of metabolic, hemodynamic, intracellular factors and growth factors/cytokines. Endocr Rev 2004;25(6):971-1010 PubMed.

3. Chen HC, Guh JY, Chang JM, Hsieh MC, Shin SJ, Lai YH. Role of lipid control in diabetic nephropathy. Kidney Int Suppl 2005;67(94):S60S62 PubMed.

4. Hovind $\mathrm{P}$, Tarnow $\mathrm{L}$, Rossing $\mathrm{K}$, et al. Decreasing incidence of severe diabetic microangiopathy in type 1 diabetes. Diabetes Care 2003;26(4):1258-1264 PubMed.

5. Yokoyama H, Okudaira M, Otani T, et al. Higher incidence of diabetic nephropathy in type 2 than in type 1 diabetes in early-onset diabetes in Japan. Kidney Int 2000;58(1):302-311.

6. Zipp T, Schelling JR. Diabetic nephropathy, in: D.E. Hricik, R.T. Miller, J.R. Sedor (Eds.) Nephrology secrets, Second edition. Hanley \& Belfus Inc. Medical Publishers, Philadelphia, 2003; 105 - 111.

7. Cooper ME, Gilbert RE. Pathogenesis, prevention, and treatment of diabetic nephropathy, in R.J. Johnson, J Feehally, (Eds.) Comprehensive clinical nephrology, second edition. Mosby, Edinburgh, 2003; 439-450. 8. Williams ME, Stanton RC. Management of diabetic kidney disease. In Kahn, C.R. Weir, G.C. King, G.L. Jacobson A.M. Moses, A.C. Smith R.J. eds. Joslin's Diabetes Mellitus. Lippincott Williams \& Wilkins, Philadelphia. 2005; 925-949.

9. Baynes JW, Thorpe SR. The role of oxidative stress in diabetic complications. Curr Opin Endocrinol Diabetes 1996;3:277-284.

10. Bonnefont-Rousselot D, Bastard JP, Jaudon MC, Delattre J.
Consequences of the diabetic status on the oxidant/antioxidant balance. Diabetes Metab 2000;26(3):163-176 PubMed.

11. Turk HM, Sevinc A, Camci C, et al. Plasma lipid peroxidation products and antioxidant enzyme activities in patients with type 2 diabetes mellitus. Acta Diabetol 2002;39(3):117-122 PubMed.

12. Cnop M, Welsh N, Jonas JC, Jörns A, Lenzen S, Eizirik DL. Mechanisms of pancreatic beta-cell death in type 1 and type 2 diabetes: many differences, few similarities. Diabetes 2005;54(Suppl 2):S97-S107 PubMed.

13. Simmons RA. Developmental origins of diabetes: the role of oxidative stress. Free Radic Biol Med 2006;40(6):917-922 PubMed.

14. Ha H, Hwang IA, Park JH, Lee HB. Role of reactive oxygen species in the pathogenesis of diabetic nephropathy. Diabetes Res Clin Pract 2008;82(Suppl 1):S42-S45 PubMed.

15. Ubani CS, Joshua PE, Oraeki AN. Influence of aqueous extract of Hibiscus sabdariffa calyces on lipid profile of phenobarbitone induced Wistar albino rats. J Pharm Res 2010;3:319-324.

16. Liu CL, Wang JM, Chu CY, Cheng MT, Tseng TH. In vivo protective effect of protocatechuic acid on tert-butyl hydroperoxide-induced rat hepatotoxicity. Food Chem Toxicol 2002;40(5):635-641 PubMed.

17. Ali BH, Mousa HM, El-Mougy S. The effect of a water extract and anthocyanins of hibiscus sabdariffa $L$ on paracetamol-induced hepatoxicity in rats. Phytother Res 2003;17(1):56-59 PubMed.

18. Asagba SO, Adaikpoh MA, Kadiri H, Obi FO. Influence of aqueous extract of Hibiscus sabdariffa L. petal on cadmium toxicity in rats. Biol Trace Elem Res 2007;115(1):47-57 PubMed.

19. Okoko T, Oruambo IF. The effect of Hibiscus sabdariffa calyx extract on cisplatin-induced tissue damage in rats. Biokemistri 2008;20(2):47-52.

20. National Research Council (NRC) Institute of Laboratory Animal 
Research. (ILAR), Guide for the Care and Use of Laboratory Animals, eighth edition, National Academy Press, Washington DC, 2011.

21. Adeyemi DO, Adewole OS. Hibiscus sabdariffa renews pancreatic $\beta$-cells in experimental type 1 diabetic model rats. Morphologie 2019;103(341 Pt 2):80-93 PubMed.

22. Adeyemi DO, Ukwenya VO, Obuotor EM, Adewole SO. Antihepatotoxic activities of Hibiscus sabdariffa $L$. in animal model of streptozotocin diabetes-induced liver damage. BMC Complement Altern Med 2014;14:277 PubMed.

23. Harborne AJ. Phytochemical methods: A Guide to Modern techniques of plants Analysis, third edition, Springer, Netherland, 1998.

24. Obouayeba AP, Djyh NB, Diabate S, et al. Phytochemical and antioxidant activity of roselle (Hibiscus Sabdariffa L.) petal extracts. Res J Pharm Biol Chem Sci 2014;5(2):1453-1465.

25. Adeyemi DO, Komolafe OA, Adewole OS, Obuotor EM, Adenowo TK. Antihyperglycaemic activities of Annona muricata (Linn), Afr. J. Trad. Complement. Altern. Med. 2009;6(1):62-69.

26. Adeyemi DO, Komolafe OA, Adewole OS, Obuotor EM, Abiodun AA, Adenowo TK. Histomorphological and morphometric studies of the pancreatic islet cells of diabetic rats treated with extracts of Annona muricata. Folia Morphol (Warsz) 2010;69(2):92-100 PubMed.

27. Drury RAB, Wallington EA. Carleton's histological technique, fifth edition., Oxford University Press, London, England, 1980.bok>

28. Ohkawa H, Ohishi N, Yagi K. Assay for lipid peroxides in animal tissues by thiobarbituric acid reaction. Anal Biochem 1979;95(2):351358 PubMed.

29. Pascual P, Martinez-Lara E, Bárcena JA, López-Barea J, Toribio F. Direct assay of glutathione peroxidase activity using highperformance capillary electrophoresis. J Chromatogr A 1992;581(1):4956 PubMed.

30. Cowell DC, Dowman AA, Lewis RJ, Pirzad R, Watkins SD. The rapid potentiometric detection of catalase positive microorganisms. Biosens Bioelectron 1994;9(2):131-138 PubMed.

31. Kahl R, Kampkötter A, Wätjen W, Chovolou Y. Antioxidant enzymes and apoptosis. Drug Metab Rev 2004;36(3-4):747-762 PubMed.

32. Blenn C, Althaus FR, Malanga M. Poly(ADP-ribose) glycohydrolase silencing protects against $\mathrm{H} 2 \mathrm{O} 2$-induced cell death. Biochem J 2006;396(3):419-429 PubMed.

33. Kirkwood BR, Sterne JAC. Essential Medical Statistics, second edition, Blackwell Science, USA, 2003.

34. Beltrán-Debón R, Alonso-Villaverde C, Aragonès G, et al. The aqueous extract of Hibiscus sabdariffa calices modulates the production of monocyte chemoattractant protein-1 in humans. Phytomedicine 2010;17(3-4):186-191 PubMed.

5. Peng $\mathrm{CH}$, Chyau CC, Chan KC, Chan TH, Wang CJ, Huang CN. Hibiscus sabdariffa polyphenolic extract inhibits hyperglycemia, hyperlipidemia, and glycation-oxidative stress while improving insulin resistance. J Agric Food Chem 2011;59(18):9901-9909 PubMed. 36. Ramírez-Rodrigues MM, Balaban MO, Marshall MR, Rouseff RL. Hot and cold water infusion aroma profiles of Hibiscus sabdariffa: fresh compared with dried. J Food Sci 2011;76(2):C212-C217 PubMed.

37. Herranz-López M, Fernández-Arroyo S, Pérez-Sanchez $A$, et al. Synergism of plant-derived polyphenols in adipogenesis: perspectives and implications. Phytomedicine 2012;19(3-4):253-261 PubMed.

38. Da-Costa-Rocha I, Bonnlaender B, Sievers H, Pischel I, Heinrich M. Hibiscus sabdariffa L. - a phytochemical and pharmacological review. Food Chem 2014;165:424-443 PubMed.

39. Reddy SV, Tiwari AK, Kumar US, Rao RJ, Rao JM. Free radical scavenging, enzyme inhibitory constituents from antidiabetic Ayurvedic medicinal plant Hydnocarpus wightiana Blume. Phytother Res 2005;19(4):277-281 PubMed.

40. Petrulea M, Muresan A, Duncea I. Oxidative stress and antioxidant status in hypo- and hyperthyroidism, in M.A. El- Missiry, (ed) Antioxidant Enzyme, Intech, Croatia, 2012; 197 - 236.

41. Lee WC, Wang CJ, Lee HJ. Antioxidants in decelerating diabetic nephropathy, in A.P. Escher, A Li (eds), Type I Diabetes. Intech, Croatia, 2013, $387-399$.

42. Lee WC, Wang CJ, Chen YH, et al. Polyphenol extracts from Hibiscus sabdariffa Linnaeus attenuate nephropathy in experimental type 1 diabetes. J Agric Food Chem 2009;57(6):2206-2210 PubMed.

43. Wang SC, Lee SF, Wang CJ, Lee CH, Lee WC, Lee HJ. Aqueous Extract from Hibiscus sabdariffa Linnaeus Ameliorate Diabetic Nephropathy via Regulating Oxidative Status and Akt/Bad/14-3-3Yin an Experimental Animal Model. Evid Based Complement Alternat Med 2009;2011:1-9.

44. Curran RC, Crocker J. Curran's Atlas of Histopathology, fourth edition, Harvey Miller, London, UK, 2000.

45. Maxwell S, Holm G, Bondjers G, Wiklund O. Comparison of antioxidant activity in lipoprotein fractions from insulin-dependent diabetics and healthy controls. Atherosclerosis 1997;129(1):89-96 PubMed.

46. Shah SV, Baliga R, Rajapurkar M, Fonseca VA. Oxidants in chronic kidney disease. J Am Soc Nephrol 2007;18(1):16-28 PubMed.

47. Singh DK, Winocour P, Farrington K. Mechanisms of disease: the hypoxic tubular hypothesis of diabetic nephropathy. Nat Clin Pract Nephrol 2008;4(4):216-226 PubMed.

48. Dalla Vestra M, Saller A, Bortoloso E, Mauer M, Fioretto P. Structural involvement in type 1 and type 2 diabetic nephropathy. Diabetes Metab 2000;26(Suppl 4):8-14 PubMed.

49. Kurutas EB. The importance of antioxidants which play the role in cellular response against oxidative/nitrosative stress: current state. Nutr J 2016;15(1):71 PubMed.

50. Niki E. Antioxidants: basic principles, emerging concepts, and problems. Biomed J 2014;37(3):106-111 PubMed.

51. Ravi K, Ramachandran B, Subramanian S. Protective effect of Eugenia jambolana seed kernel on tissue antioxidants in streptozotocin-induced diabetic rats. Biol Pharm Bull 2004;27(8):12121217 PubMed.

52. Viswanathan $V$, Snehalatha C, Kumutha $R$, Jayaraman $M$, Ramachandran A. Serum albumin levels in different stages of type 2 diabetic nephropathy patients. Indian J Nephrol 2004;14:89-92

53. Lal SS, Sukla Y, Singh A, Andriyas EA, Lall AM. Hyperuricemia, high serum urea and hypoproteinemia are the risk factor for diabetes. Asian J Med Sci 2009;1:33-34.
Received: February 16, 2019

Accepted: August 14, 2019
Corresponding author

David Olawale Adeyemi

Email:waledavade@yahoo.com 